\title{
MONOPHYLY OF THE MOITESSIERIIDAE BOURGUIGNAT, 1863 (CAENOGASTROPODA: TRUNCATELLOIDEA)
}

\author{
ANDRZEJ FALNIOWSKI ${ }^{1 *}$, SimONA PREVORČNIK², TEO DELIĆ2 ${ }^{2}$ ROMAN ALTHER ${ }^{3,4}$, \\ FLORIAN ALTERMATT ${ }^{3,4}$, SEBASTIAN HOFMAN ${ }^{5}$
}

\begin{abstract}
${ }^{1}$ Department of Malacology, Institute of Zoology and Biomedical Research, Jagiellonian University, Gronostajowa 9, 30-387 Cracow, Poland (e-mail: andrzej.falniowski@uj.edu.pl); (1) https://orcid.org/0000-0002-3899-6857

${ }^{2}$ Department of Biology, Biotechnical Faculty, University of Ljubljana, Jamnikarjeva 101, 1000 Ljubljana, Slovenia; TD (1) https://orcid.org/0000-0003-4378-5269

${ }^{3}$ Department of Evolutionary Biology and Environmental Studies, University of Zurich, Winterthurerstr. 190, CH-8057 Zürich, Switzerland; RA (1) https://orcid.org/0000-0001-7582-3966, FA (1) https://orcid.org/0000-0002-4831-6958

${ }^{4}$ Eawag, Swiss Federal Institute of Aquatic Science and Technology, Department of Aquatic Ecology, Überlandstrasse 133, CH-8600 Dübendorf, Switzerland

${ }^{5}$ Department of Comparative Anatomy, Institute of Zoology and Biomedical Research, Jagiellonian University, Gronostajowa 9, 30-387 Cracow, Poland; i https://orcid.org/0000-0001-6044-3055

*corresponding author
\end{abstract}

\begin{abstract}
The family Moitessieriidae is poorly known, as its members, inhabiting exclusively subterranean waters, are often known only from few minute, empty shells. Molecular studies on their relationships confirmed the distinctness of this family. Their monophyly, however, remained doubtful, since the Moitessieriidae did not form a distinct clade in the phylogenetic tree based on the most commonly applied mitochondrial cytochrome oxidase subunit I (COI), and the representative of the family Cochliopidae occupied a position among the moitessieriid clades. In the present paper two new nuclear loci, namely histone $\mathrm{H} 3$ gene and ribosomal internal transcribed spacer ITS2, have been applied to resolve the status of the Moitessieriidae. The resulting phylogenies show the Moitessieriidae as a distinct, well supported clade, confirming thus their monophyly.
\end{abstract}

KEY WORDS: Moitessieriidae, molecular phylogeny, COI, H3, 18S, ITS2

\section{INTRODUCTION}

The family Moitessieriidae Bourguignat, 1863 is probably the least studied group of the European Truncatelloidea. It includes minute dioecious gastropods (Figs 1-11) exclusively inhabiting subterranean waters, including thermal ones (SKET \& VELKOVRH 1981). For most species only empty shells are known. Hence, dozens of nominal species have been described without anatomical and molecular data (e.g. GLÖER 2002), and their distinctness as well as their relationships remain unknown. Comparative mo- lecular data have only recently begun to accumulate (WILKE et al. 2001, 2013, RICHLING et al. 2016, ANGYAL et al. 2018, HofMAN et al. 2018), but it is already evident that the morphology-based levels of endemism are overestimated in the Moitessieriidae (FALNIOWSKI et al. 2014).

The morphology and anatomy of the soft parts are still poorly studied. The detailed anatomy of Bythiospeum Bourguignat, 1882 was described and illustrated by HAASE (1995). Some anatomical 


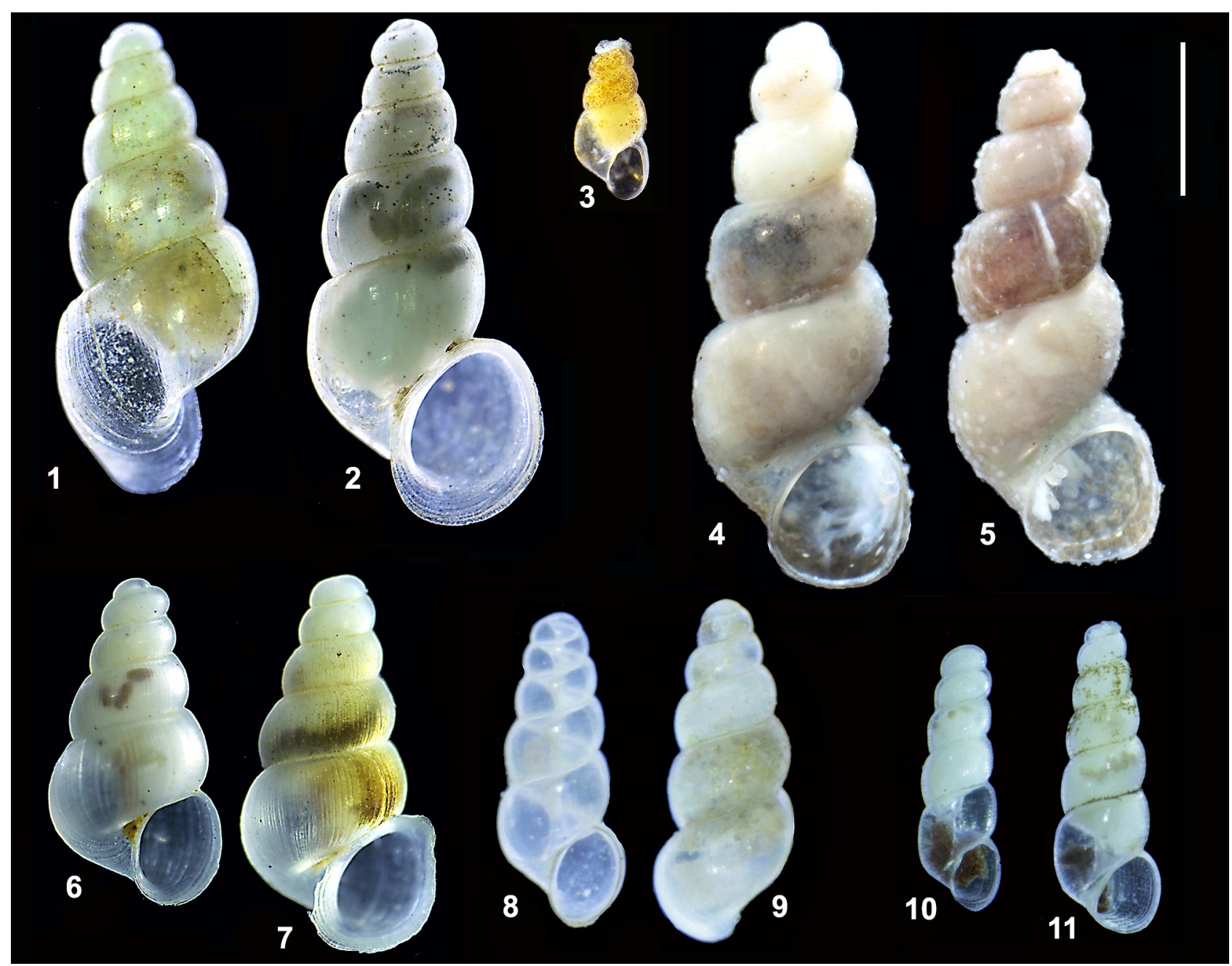

Figs 1-11. Shells of the Moitessieriidae: 1-2 - Paladilhiopsis grobbeni Kuščer, 1928; 3 - Bythiospeum acicula (Hartmann, 1821); 4-5 - Iglica hellenica Falniowski et Sarbu, 2015; 6-7 - Costellina turrita Kuščer, 1933; 8-9 - Iglica cf. forumjuliana (Pollonera, 1887); 10-11-Moitessieria sp. (after HOFMAN et al. 2018, except 3); scale bar $1 \mathrm{~mm}$

data on the Moitessieriidae were contributed also by Bole (1961, 1970), Giusti \& Pezzoli (1980) (anatomy of Iglica Wagner, 1927 and Paladilhiopsis Pavlović, 1913), BERNASCONI (1990, 1994), BOETERS \& GitTenberger (1990), BODON \& GiUsti (1991), BOETERS (1998), SZAROWSKA (2006) and NIERO \& PEZZOLI (2016), summarised by WiLKE et al. (2013). The character states unique for the Moitessieriidae are: pyriform metapodial tentacle, and intestine with a long, wide and loose loop around the style sac. The character states of moitessieriids that are uncommon among the Truncatelloidea are: smooth protoconch; all soft parts unpigmented; ctenidium reduced or absent; and osphradium small, less than twice as long as broad (HOFMAN et al. 2018). The distinctness of the Moitessieriidae has been questioned: BODON \& GIUSTI (1991) considered its representatives to belong to the Hydrobiidae.

Molecular data (WILKE et al. 2001, 2013, HOFMAN et al. 2018) have confirmed the distinctness of the Moitessieriidae. However, HOFMAN et al. (2018) found that the family Cochliopidae was nested among the moitessieriid clades based on a cytochrome oxidase subunit I (COI) tree and, despite the low associated bootstrap values, the monophyly of the family Moitessieriidae was not supported. This was in contrast to findings of WILKE et al. (2013), who reported its monophyly; it should be noted, though, that the family representatives failed to form a distinct clade, and neither Iglica nor Paladilhiopsis were included in the phylogenetic analysis. In the COI tree of HOFMAN et al. (2018) there was a well-supported clade containing all the Balkan Paladilhiopsis and Iglica hellenica Falniowski et Sarbu, 2015, another well supported clade of I. cf. gracilis (Clessin, 1882) (both formed a weakly supported clade), a third well-supported clade of the Cochliopidae, and the fourth well-supported clade grouping together all members of the "real" Bythiospeum. These four clades formed an unresolved polytomy together with Sardopaladilhia Manganelli, Bodon, Cianfanelli, Talenti et Giusti, 1998 and Moitessieria Bourguignat, 1863. Bootstrap supports were very low, thus the Moitessieriidae did not form a well supported clade. Unfortunately, as only the 
COI sequences could be retrieved from GenBank and no Bythiospeum material was available for sequencing any nuclear loci at that time, the problem remained

\section{MATERIAL AND METHODS}

Specimens of Bythiospeum acicula (Hartmann, 1821) (Fig. 3) were collected in Switzerland, Kollbrunn, site

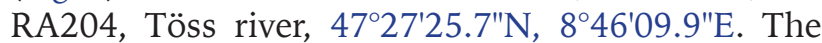
Bou-Rouch method (Bou \& RoUCH 1967) was used to sample a gravel bar of the river. At the same place also the recently described interstitial amphipod species Niphargus tonywhitteni was found (FIŠER et al. 2018). The collection localities of all the other moitessieriid taxa have been described in HOFMAN et al. (2018). Samples were preserved in $96 \%$ ethanol. All the techniques of fixation, DNA extraction and PCR conditions were exactly the same as in SZAROWSKA et al. (2016a, b) for mitochondrial cytochrome oxidase subunit I (COI), nuclear 18S ribosomal RNA (18S), and nuclear histone $\mathrm{H} 3(\mathrm{H} 3)$. For internal transcribed spacer 2 (ITS2) the following primers were used: NEWS2-F 5'-TGTGTCGATGAAGAACGCAG-3'; and ITS2-RIXO 5'-TTCTATGCTTAAATTCAGGGG-3';

\section{RESULTS AND DISCUSSION}

The identification of our specimen of Bythiospeum needs some explanation. In the Swiss faunistic list (Centre Suisse de Carthographie de la Faune CSCF) Bythiospeum haeussleri (Clessin, 1910) is recorded from the same region as our Bythiospeum. However, our sequence is identical with the ones from GenBank, representing five nominal species (Fig. 12). According to the ICZN, namely the priority rule, the name Bythiospeum acicula (Held, 1838) is appropriate for this taxon. According to RICHLING et al. (2016), B. haeussleri, known from Switzerland, belongs to their clade 3, and B. acicula, inhabiting Germany NE of our Swiss locality, belongs to their clade 1 , their sequences are markedly different one from another. B. acicula has not been recorded from Switzerland so far, but RICHLING et al. (2016) suggest that its range could also reach Switzerland.

Finally, we obtained 16 sequences of $18 \mathrm{~S}$ (286 bp, GenBank Accession numbers MK629727-MK629742), 16 sequences of ITS2 (310 bp, GenBank Accession numbers MK629747-MK629762), three sequences of H3 (310 bp, GenBank Accession numbers MK609534MK609536) and one of COI (488 bp, GenBank Accession number MK609537). In both coding loci the tests of XIA et al. (2003) revealed no saturation. The cytochrome oxidase tree including our specimen of Bythiospeum (Fig. 12) showed again the clade which consisted of the representatives of the Cochliopidae unresolved. The aim of the present paper is to test the monophyly of the Moitessieriidae by investigating nuclear loci.

ALMEYDA-ARTIGAS et al. 2000). The PCR conditions (Phusion High-Fidelity DNA Polymerase) were as follows: initial denaturation step of $1 \mathrm{~min}$ at $98^{\circ} \mathrm{C}$, followed by 36 cycles of $10 \mathrm{~s}$ at $98^{\circ} \mathrm{C}, 10 \mathrm{~s}$ at $48^{\circ} \mathrm{C}, 20 \mathrm{~s}$ at $72{ }^{\circ} \mathrm{C}$, and a final extension of $5 \mathrm{~min}$ at $72^{\circ} \mathrm{C}$. The saturation test (XIA et al. 2003) for the coding genes was performed using DAMBE (XIA 2013). Sequences were initially aligned in the MUSCLE (EDGAR 2004) algorithm integrated in MEGA 6 (TAMURA et al. 2013). Names of taxa used for phylogenetic inference, GenBank accession numbers of sequences and their references are provided in Table 1. Phylogenetic inference was run applying maximum likelihood technique with RAxML (STAMATAKIS 2014), estimating with RAxML appropriate parameters of the GTR+I model for each partition of concatenated sequences, in the coding ones each codon position treated in the same way.

Tryon, 1866, within the polytomy formed by three clades of the Moitessieriidae (Moitessieria/ Sardopaladilhia, Bythiospeum and Iglica/Paladilhiopsis), as also in HoFmAN et al. (2018). In the tree of $18 \mathrm{~S}$ (not shown) the Moitessieriidae were far from the Cochliopidae, but all the bootstrap supports were low. In the tree of nuclear H3 (Fig. 13) the Moitessieriidae formed a distinct, well supported clade (bootstrap support $74 \%$ ). Interestingly, Bythiospeum was close to Iglica, not to Paladilhiopsis, which confirmed the results of HOFMAN et al. (2018), but not those of BOETERS (1998). The latter author synonymised Paladilhiopsis with Bythiospeum, based on the similarity of the general structure of the female reproductive organs, i.e., a large bursa copulatrix situated at the proximal part of the albumen gland, which is markedly shortened. These character states were regarded as a result of parallelism by HOFMAN et al. (2018).

The tree from concatenated sequences of all nuclear loci (Fig. 14) grouped all Moitessieriidae taxa in one well supported clade $(76 \%)$. The same applies to the tree from concatenated sequences of both, nuclear and mtCOI loci (support 71\%). There are no strict rules concerning the significance levels of the bootstrap, but usually the values exceeding $70 \%$ are accepted as significant. Thus, we consider the Moitessieriidae as monophyletic, although closely related to Cochliopidae. 


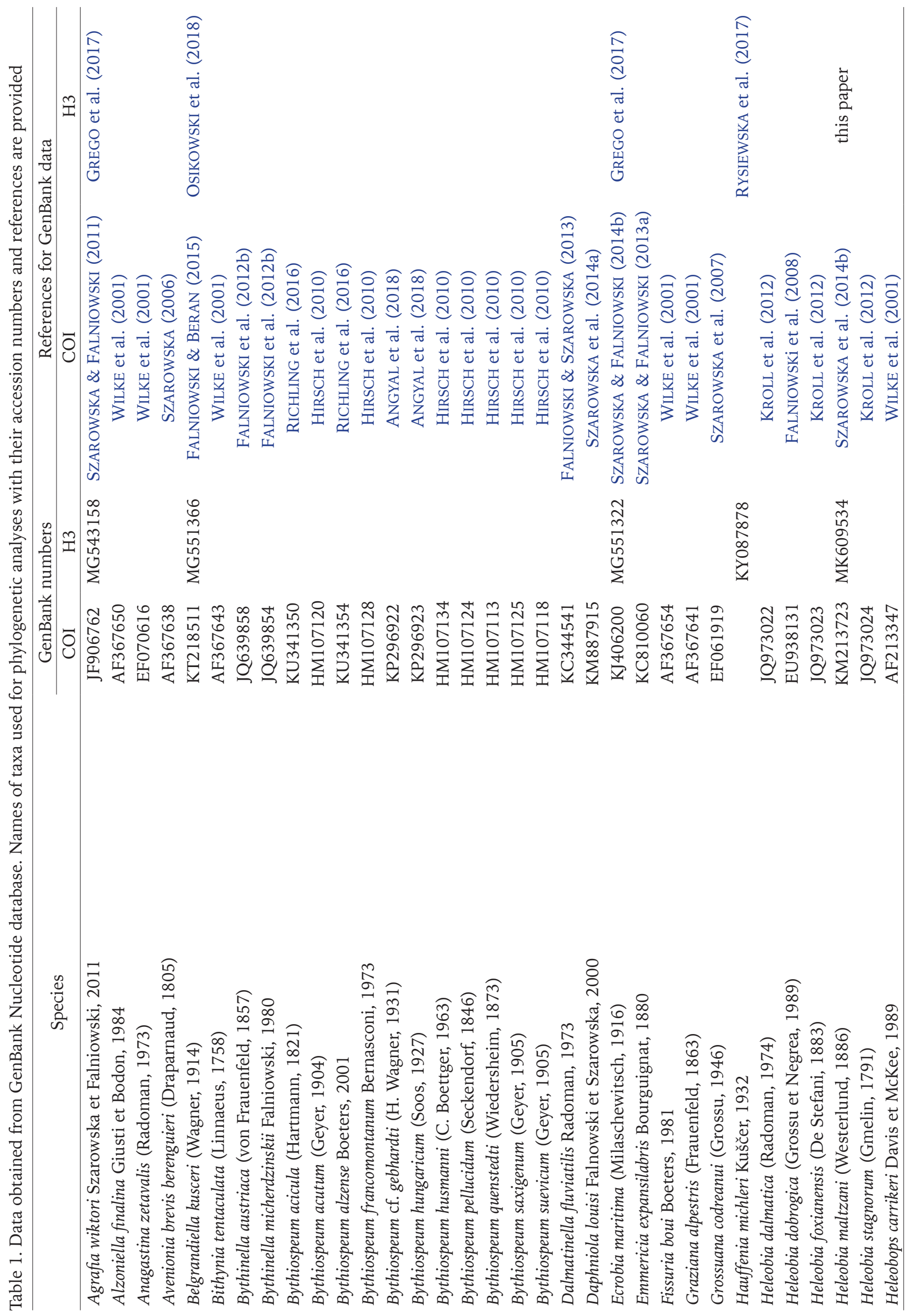



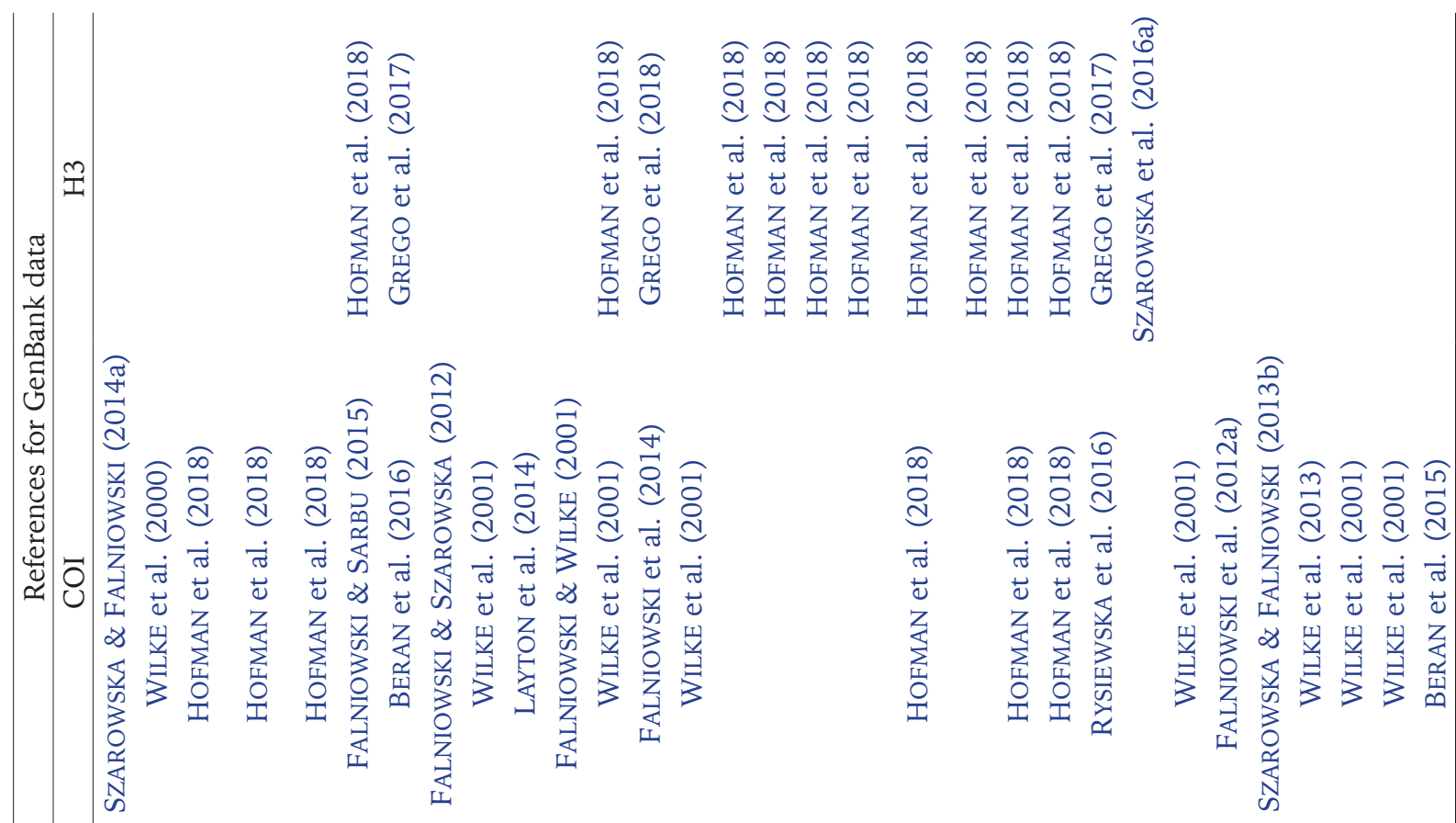

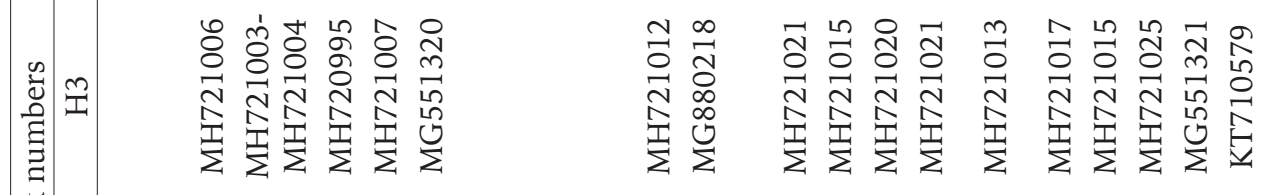

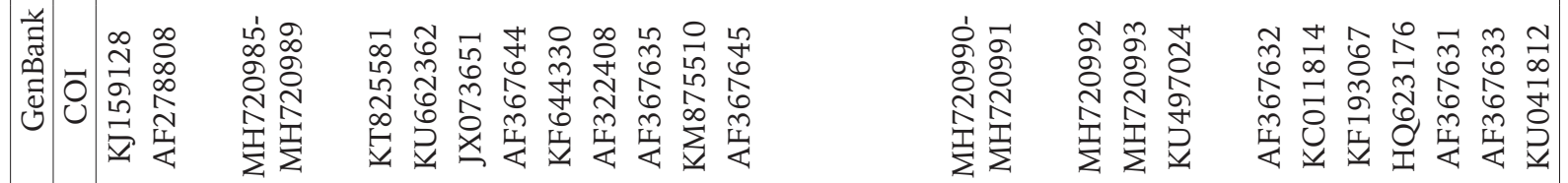

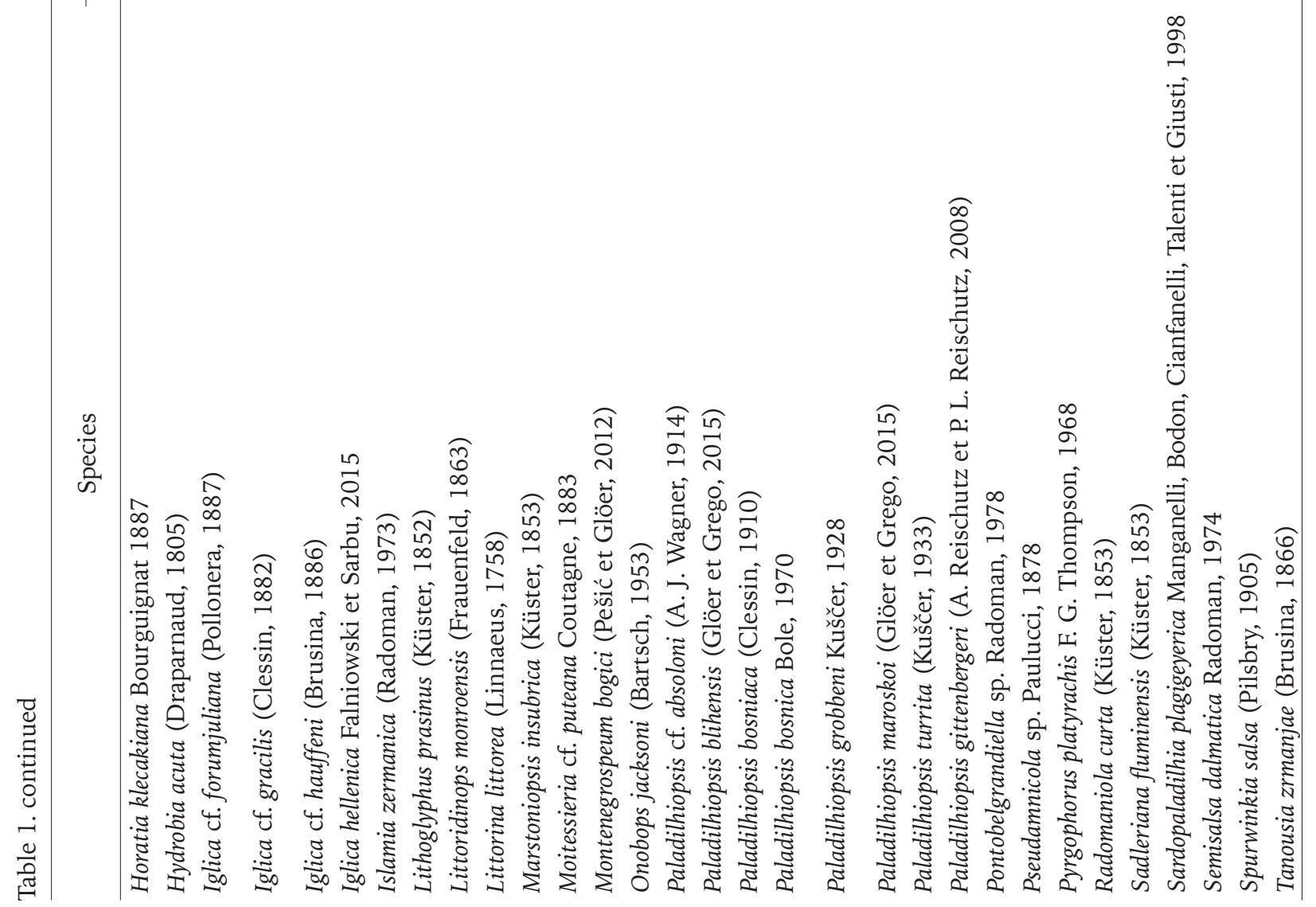




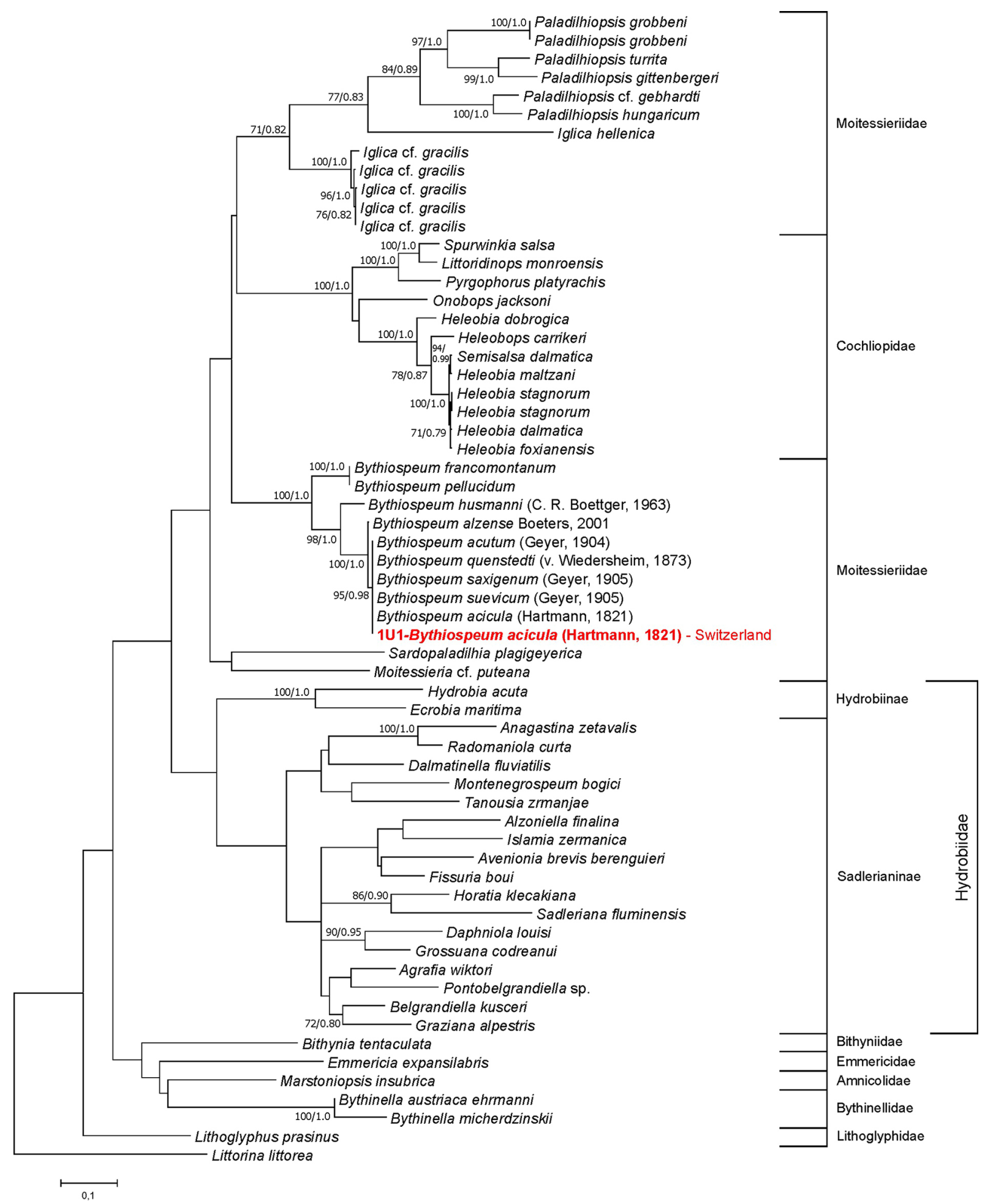

Fig. 12. Maximum likelihood tree of cytochrome oxidase subunit I (COI); bootstrap supports and Bayesian posterior probabilities given. New sequence marked by red bold 


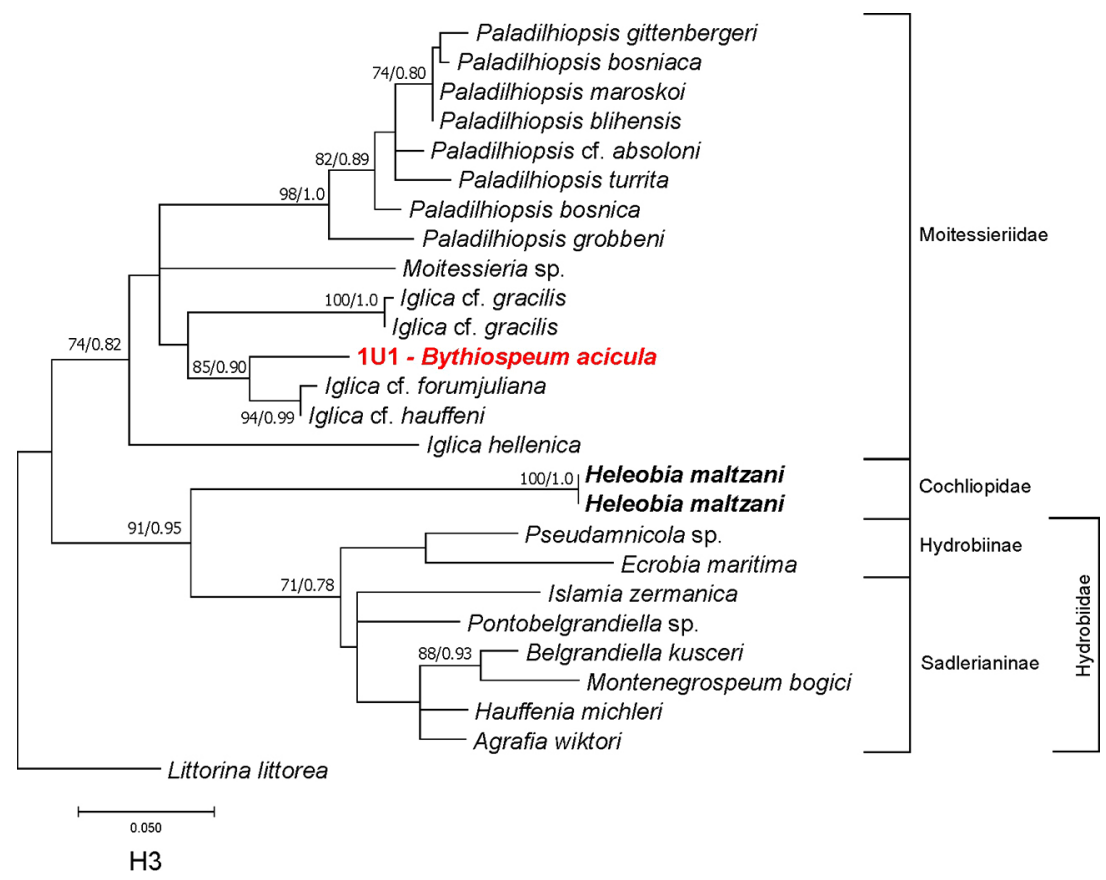

Fig. 13. Maximum likelihood tree of histone H3; bootstrap supports and Bayesian probabilities given. New sequences marked by bold
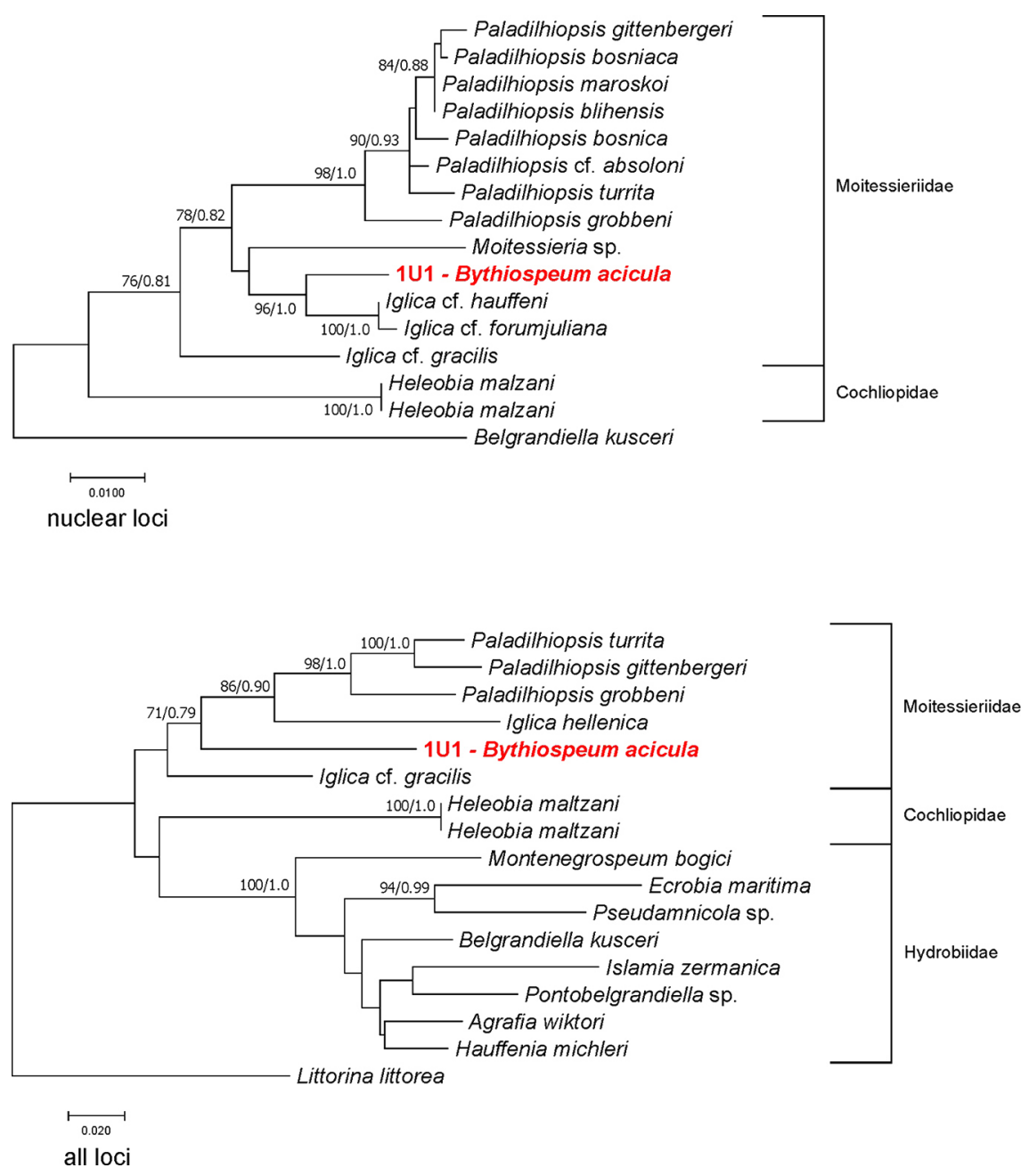

Fig. 14. Maximum likelihood tree of concatenated nuclear loci (including ITS2; above) and concatenated nuclear and mtCOI loci (below); bootstrap supports and Bayesian probabilities given above the branches. New sequences marked by bold 


\section{REFERENCES}

Almeyda-ARtigas R., BARgues D. M., MAS-Coma S 2000. ITS-2 rDNA sequencing of Gnathostoma species (Nematoda) and elucidation of the species causing gnathostomiasis in the Americas. Journal of Parasitology 86: 357-544. https://doi.org/10.1645/0022-3395(200 0)086[0537:IRSOGS]2.0.CO;2

ANGyAl D., BALÁZS G., KRÍZSIK V., HeRCZEG G., FEHÉR Z. 2018. Molecular and morphological divergence in a stygobiont gastropod lineage (Truncatelloidea, Moitessieriidae, Paladilhiopsis) within an isolated karstic area in the Mecsek Mountains (Hungary). Journal of Zoological Systematics and Evolutionary Research 56: 493-504. https://doi.org/10.1111/jzs.12220

BERAN L., HOFMAN S., FALNIOWSKI A. 2015. Tanousia zrmanjae (Brusina, 1866) (Caenogastropoda: Truncatelloidea: Hydrobidae): A living fossil. Folia Malacologica 23: 263-271. https://doi.org/10.12657/folmal.023.022

BERAN L., OSIKOWSKI A., HOFMAN S., FALNIOWSKI A. 2016. Islamia zermanica (Radoman, 1973) (Caenogastropoda: Hydrobidae): morphological and molecular distinctness. Folia Malacologica 24: 25-30. https://doi. org/10.12657/folmal.024.004

BERNASCONI R. 1990. Revision of the genus Bythiospeum (Mollusca Prosobranchia Hydrobiidae) of France, Switzerland and Germany. Länggass-Druck, Bern.

BERNASCONI R. 1994. Le genre Moitessieria Bgt, 1863, en France: révision, inventaire et description de $M$. corsica n. sp. (Mollusca Gasteropoda Prosobranchia Hydrobiidae). Mémoires de Biospéologie 21: 7-20.

BodON M., GIUSTI F. 1991. The genus Moitessieria in the island of Sardinia and in Italy. New data on the systematics of Moitessieria and Paladilhia (Prosobranchia: Hydrobiidae) (Studies on the Sardinian and Corsican malacofauna, IX). Malacologia 33: 1-30.

Boeters H. D. 1998. Mollusca: Gastropoda: Superfamilie Rissooidea. In: SCHWOERBEL J., ZWICK P. (eds). Süsswasserfauna von Mitteleuropa. Begründet von A. Brauer. 5/1-2. Gustav Fischer Verlag, Jena/Lübeck/ Ulm, pp. 1-76.

Boeters H. D., GitTEnBerger E. 1990. Once more on the Moitessieriidae (Gastropoda Prosobranchia), with the description of Clameia brooki gen. et spec. nov. Basteria 54: 123-129.

BOLE J. 1961. Nove Hidrobide (Gastropoda) iz podzemeljskih voda zahodnega Balkana. Biološki Vestnik 9: 59-69.

BOLE J. 1970. Prispevek k poznavanju anatomije in taksonomije podzemeljskih hidrobiid (Gastropoda, Prosobranchia). Razprave SAZU, Ljubljana, IV, 10: 73-108.

BOU C., Rouch R. 1967. Un nouveau champ de recherches sur la faune aquatique souterraine. Compte Rendus Academie Sciences Paris 265: 369-370.

EDGAR R. C. 2004. MUSCLE: multiple sequence alignment with high accuracy and high throughput. Nucleic Acids Research 32: 1792-1797. https://doi.org/10.1093/nar/ gkh340
FALNIOWSKI A., BERAN L. 2015. Belgrandiella A. J. Wagner, 1928 (Caenogastropoda: Truncatelloidea: Hydrobiidae): how many endemics? Folia Malacologica 23: 187-191. https://doi.org/10.12657/folmal.023.015

FALNIOWSKI A., SARBU S. 2015. Two new Truncatelloidea species from Melissotrypa Cave in Greece (Caenogastropoda). ZooKeys 530: 1-14. https://doi. org/10.3897/zookeys.530.6137

FALNIOWSKI A., SZAROWSKA M. 2012. Species distinctness of Lithoglyphus prasinus (Küster, 1852) (Rissooidea: Caenogastropoda). Folia Malacologica 20: 99-104. https://doi.org/10.2478/v10125-012-0019-x

FALNIOWSKI A., SZAROWSKA M. 2013. Phylogenetic relationships of Dalmatinella fluviatilis Radoman, 1973 (Caenogastropoda: Rissooidea). Folia Malacologica 21: 1-7. https://doi.org/10.12657/folmal.021.001

FALNIOWSKI A., WILKE T. 2001. The genus Marstoniopsis (Rissooidea: Gastropoda): intra- and intergeneric phylogenetic relationships. Journal of Molluscan Studies 67: 483-488. https://doi.org/10.1093/mollus/67.4.483

FALNIOWSKI A., SZAROWSKA M., SiRBU I., HillEBRAND A., BACIU M. 2008. Heleobia dobrogica (Grossu \& Negrea, 1989) (Gastropoda: Rissooidea: Cochliopidae) and the estimated time of its isolation in a continental analogue of hydrothermal vents. Molluscan Research 28: 165-170.

FALNIOWSKI A., SZAROWSKA M., GLÖER P., PEŠIĆ V. 2012a. Molecules vs. morphology in the taxonomy of the Radomaniola/Grossuana group of Balkan Rissooidea (Mollusca: Caenogastropoda). Journal of Conchology 41: 19-36.

FALNIOWSKI A., SZAROWSKA M., GLÖER P., PEŠIĆ V., GEORGIEV D., HORSAK M., SIRBU I. 2012b. Radiation in Bythinella (Mollusca: Gastropoda: Rissooidea) in the Balkans. Folia Malacologica 20: 1-9. https://doi. org/10.2478/v10125-012-0006-2

FALNIOWSKI A., PEŠIĆ V., GLÖER P. 2014. Montenegrospeum Pešić et Glöer, 2013: a representative of Moitessieriidae? Folia Malacologica 22: 263-268. https://doi. org/10.12657/folmal.022.023

FIŠER C., ALThER R., ZAKŠEK V., BORKO Š., FUCHS A., AltermatT F. 2018. Translating Niphargus barcodes from Switzerland into taxonomy with a description of two new species (Amphipoda, Niphargidae). ZooKeys 760: 113-141. https://doi.org/10.3897/zookeys.760.24978

GiUsti F., Pezzoli E. 1980. Guide per il riconoscimento delle specie animali delle acque interne Italiane 8. Gasteropodi 2 (Gastropoda: Prosobranchia; Hydrobioidea, Pyrguloidea). Consiglio Nazionale delle Ricerche, Verona.

GLÖER P. 2002. Die Süsswassergastropoden Nord- und Mitteleuropas, Bestimmungsschlüssel, Lebensweise, Verbreitung. Die Tierwelt Deutschlands. Vol. 73. ConchBooks, Hackenheim.

Grego J., HofmAN S., MuMLADZE L., FALNIOWSKI A. 2017. Agrafia Szarowska et Falniowski, 2011 (Caenogastropoda: Hydrobiidae) in the Caucasus. Folia Malaco- 
logica 25: 237-247. https://doi.org/10.12657/folmal.025.025

GREGO J., GLÖER P., RYSIEWSKA A., HOFMAN S., FALNIOWSKI A. 2018. A new Montenegrospeum species from south Croatia (Mollusca: Gastropoda: Hydrobiidae). Folia Malacologica 26: 25-34. https://doi.org/10.12657/folmal.026.004

HAASE M. 1995. The stygobiont genus Bythiospeum in Austria: a basic revision and anatomical description of $B$. cf. geyeri from Vienna (Caenogastropoda: Hydrobiidae). American Malacological Bulletin 11: 123-137.

Hirsch J., Niederhoefer H.-J., Blum M., BRUemmer F., PfannkUChen M., SCHILl R., FALKNeR G. 2010. First phylogenetic insights into the genus Bythiospeum (Gastropoda: Hydrobiidae) inferred from COI gene sequences (unpublished). Available on-line at https:// www.ncbi.nlm.nih.gov/nuccore/ (accessed 16 February 2019)

Hofman S., RYSiEWSKa A., OSIKOWSKI A., Grego J., SKET B., PREVORČNIK S., ZAGMAJSTER M., FALNIOWSKI A. 2018. Phylogenetic relationships of the Balkan Moitessieriidae (Caenogastropoda: Truncatelloidea). Zootaxa 4486: 311-339. https://doi.org/10.11646/zootaxa. 4486.3 .5

Kroll O., Hershler R., Albrecht C., Terrazas E. M., Apaza R., Fuentealba C., WolfF C., Wilke T. 2012. The endemic gastropod fauna of Lake Titicaca: correlation between molecular evolution and hydrographic history. Ecology and Evolution 2: 1517-1530. https:// doi.org/10.1002/ece3.280

Layton K. K., Martel A. L., Hebert P. D. 2014. Patterns of DNA barcode variation in Canadian marine molluscs. PLoS ONE 9: e95003. https://doi.org/10.1371/journal. pone.0095003

Niero I., PeZzoli E. 2016. Una nuova specie di Iglica Wagner, 1910 per la Lombardia (Gastropoda: Prosobranchia: Moitessieriidae). Bolletino Malacologico 42: 1-29.

OsIKOWSKI A., HOFMAN S., RYSIEWSKA A., SKET B., PREVORČNIK S., FALNIOWSKI A. 2018. A case of biodiversity overestimation in the Balkan Belgrandiella A. J. Wagner, 1927 (Caenogastropoda: Hydrobiidae): molecular divergence not paralleled by high morphological variation. Journal of Natural History 52: 5-6, 323-344. https://doi.org/10.1080/00222933.2018.1424959

RICHLING I., MALKOWSKY Y., KUHN Y., NIEDERHÖFER H.-J., BOETERS H. D. 2016. A vanishing hotspot - impact of molecular insights on the diversity of Central European Bythiospeum Bourguignat, 1882 (Mollusca: Gastropoda: Truncatelloidea). Organism Diversity \& Evolution 17: 67-85. https://doi.org/10.1007/s13127-016-0298-y

RYSIEWSKA A., GEORGIEV D., OSIKOWSKI A., HOFMAN S., FALNIOWSKI A. 2016. Pontobelgrandiella Radoman, 1973 (Caenogastropoda: Hydrobiidae): A recent invader of subterranean waters? Journal of Conchology 42: 193203.

RYSIEWSKa A., PrevorČniK S., OSIKOWSKI A., HOFMAN S., BERAN L., FALNIOWSKI A. 2017. Phylogenetic relationships in Kerkia and introgression between Hauffenia and Kerkia (Caenogastropoda: Hydrobiidae). Journal of
Zoological Systematics and Evolutionary Research 55: 106-117. https://doi.org/10.1111/jzs.12159

SKET B., VelKovRH F. 1981. Podzemeljske živali v termalnih vodah. Biološki Vestnik 29: 91-120.

STAMATAKIS A. 2014. RAxML version 8: a tool for phylogenetic analysis and post-analysis of large phylogenies. Bioinformatics 30: 1312-1313. https://doi. org/10.1093/bioinformatics/btu033

SZAROWSKA M. 2006. Molecular phylogeny, systematics and morphological character evolution in the Balkan Rissooidea (Caenogastropoda). Folia Malacologica 14: 99-168. https://doi.org/10.12657/folmal.014.014

SZAROWSKA M., FALNIOWSKI A. 2011. An unusual, flagellum-bearing hydrobiid snail (Gastropoda: Rissooidea: Hydrobiidae) from Greece, with descriptions of a new genus and a new species. Journal of Natural History 45: 2231-2246. https://doi.org/10.10 80/00222933.2011.591067

SZAROWSKA M., FALNIOWSKI A. 2013a. Phylogenetic relationships of the Emmericiidae (Caenogastropoda: Rissooidea). Folia Malacologica 21: 67-72. https://doi. org/10.12657/folmal.021.007

SZAROWSKA M., FALNIOWSKI A. 2013b. Species distinctness of Sadleriana robici (Clessin, 1890) (Gastropoda: Rissooidea). Folia Malacologica 21: 127-133. https:// doi.org/10.12657/folmal.021.016

SZAROWSKA M., FALNIOWSKI A. 2014a. Horatia Bourguignat, 1887: is this genus really phylogenetically very close to Radomaniola Szarowska, 2006 (Caenogastropoda: Rissooidea). Folia Malacologica 22: 31-39. https://doi. org/10.12657/folmal.022.003

SZAROWSKA M., FALNIOWSKI A. 2014b. Ventrosia mariti$m a$ (Milaschewitsh, 1916) and V. ventrosa (Montagu, 1803) in Greece: molecular data as a source of information about species ranges within the Hydrobiinae (Caenogastropoda: Truncatelloidea). Folia Malacologica 22: 61-67. https://doi.org/10.12657/folmal.022.006

SZAROWSKA M., GRZMIL P., FALNIOWSKI A., SIRBU I. 2007. Grossuana codreanui (Grossu, 1946) and the phylogenetic relationships of the East Balkan genus Grossuana (Radoman, 1973) (Gastropoda: Rissooidea). Hydrobiologia 579: 379-391. https://doi.org/10.1007/ s10750-006-0530-4

SZAROWSKA M., HOFMAN S., OSIKOWSKI A., FALNIOWSKI A. 2014a. Daphniola Radoman, 1973 (Caenogastropoda: Truncatelloidea) at east Aegean islands. Folia Malacologica 22: 269-275. https://doi.org/10.12657/ folmal.022.021

SZAROWSKA M., HOFMAN S., OSIKOWSKI A., FALNIOWSKI A. 2014b. Heleobia maltzani (Westerlund, 1886) (Caenogastropoda: Truncatelloidea: Cochliopidae) from Crete and species-level diversity of Heleobia Stimpson, 1865 in Europe. Journal of Natural History 48: 2487-2500. https://doi.org/10.1080/00222933.20 14.946109

SZAROWSKA M., OsIKOWSKI A., HOFMAN S., FALNIOWSKI A. 2016a. Pseudamnicola Paulucci, 1878 (Caenogastropoda: Truncatelloidea) from the Aegean Islands: a long or short story? Organism Diversity \& Evolution 16: $121-$ 139. https://doi.org/10.1007/s13127-015-0235-5 
SZAROWSKA M., OSIKOWSKI A., HOFMAN S., FALNIOWSKI A. 2016b. Do diversity patterns of the spring-inhabiting snail Bythinella (Gastropoda, Bythinellidae) on the Aegean Islands reflect geological history? Hydrobiologia 765: 225-243. https://doi.org/10.1007/s10750-0152415-X

TAMURA K., Stecher G., Peterson D., Filipski A., Kumar S. 2013. MEGA6: molecular evolutionary genetics analysis version 6.0. Molecular Biology and Evolution 30: 2725-2729. https://doi.org/10.1093/molbev/mst197

Wilke T., Rolán E., DAVIS G. M. 2000. The mudsnail genus Hydrobia s.s. in the northern Atlantic and western Mediterranean: a phylogenetic hypothesis. Marine Biology 137: 827-833. https://doi.org/10.1007/ s002270000407

Wilke T., DAVIS G. M., FALNIOWSKI A., GiUsti F., BODON M., SZAROWSKA M. 2001. Molecular systematics of Hydrobiidae (Mollusca: Gastropoda: Rissooidea): testing monophyly and phylogenetic relationships. Proceedings of the Academy of Natural Sciences Philadelphia 151: 1-21. https:// doi.org/10.1635/0097-3157(2001)151 [0001:MSOHMG]2.0.CO;2

Wilke T., HaAse M., Hershler R., LiU H.-S., Misof B., PONDER W. 2013. Pushing short DNA fragments to the limit: Phylogenetic relationships of 'hydrobioid' gastropods (Caenogastropoda: Rissooidea). Molecular Phylogenetics and Evolution 66: 715-736. https://doi. org/10.1016/j.ympev.2012.10.025

XIA X. 2013. DAMBE: A comprehensive software package for data analysis in molecular biology and evolution. Molecular Biology and Evolution 30: 1720-1728. https://doi.org/10.1093/molbev/mst064

Xia X., Xie Z., Salemi M., Chen L., Wang Y. 2003. An index of substitution saturation and its application. Molecular Phylogenetics and Evolution 26: 1-7. https:// doi.org/10.1016/S1055-7903(02)00326-3

Received: December 17th, 2018

Revised: February 13th, 2019

Accepted: February 26th, 2019

Published on-line: March 19th, 2019 